\title{
Learning Clean, Healthy and Safe Life Behavior in Inclusive Early Childhood Education
}

\author{
Widya Ayu Puspita ${ }^{1, *}$ Minarni Puji Sulistyorini ${ }^{1}$ Bintoro Wibowo ${ }^{1}$
}

\begin{abstract}
${ }^{1}$ Balai Pengembangan Pendidikan Anak Usia Dini dan Pendidikan Masyarakat Jawa Timur, Surabaya, Indonesia *Corresponding author. Email: widyaayu.surabaya@gmail.com
\end{abstract}

\begin{abstract}
The Clean, Healthy and Safe Lifestyle Learning Model in Inclusive Early Childhood Education is a habituation and conditioning program in play groups. The programme aims to make those behavior become a habit. Program development is carried out using a quantitative research approach, with quasi-experimental designs. The total target is 80 children. Clean, healthy and safe behavior is focused on washing hands properly, brushing teeth, removing trash in its place, consumption of nutritious, healthy and balanced food and safe behavior. The results of the development show that all behavior can be taught for all children, even though their developmental achievements are different. All children without special needs can wash their hands in seven steps, but $80 \%$ have not been able to do it in sequence. Children with special needs can only do three steps. $70 \%$ of children without special needs can brush their teeth with five steps. All children without special needs can dispose of trash in the right place, and all children with special needs can dispose of trash in its place with the guidance of teacher. $95 \%$ of children without special needs can consume a variety of foods, all children with special needs can consume food according to their specialty. The conclusion is that all children can be familiarized and conditioned to have a clean, healthy and safe lifestyle. It is recommended that research and development related to children basic life skills, and increase the ability of family and teacher to accompany children can habituate these behaviors.
\end{abstract}

Keywords: Behavior, clean life, healthy, safe, early childhood, inclusive, children with special needs

\section{INTRODUCTION}

Clean, healthy and safe behavior is an attitude, knowledge and skills related to various efforts to maintain cleanliness, health and personal safety and the environment. The Clean, Healthy and Safe Lifestyle Learning Model in Inclusive Early Childhood Education is a learning program to familiarize children in playgroups, both children in general and children with special needs. The habituation is integrated in all activities throughout the day and reinforced on certain related themes. Targets are limited to 2-4 years or those that are in inclusive playgroup institutions. For children with special needs, the age range is not limited to 2-4 years, but the most important thing is in the playgroup. The implementation of the model is strongly supported by the active involvement of teacher as activity designers and managers who monitor activities while controlling the quality of learning.

Clean, healthy and safe behavior consists of several behaviors, including washing hands, brushing teeth, taking out the trash in its place, consuming healthy and balanced food, urinating and defecating in its place, and maintaining environmental cleanliness. In this model the focus is on washing hands, brushing teeth, taking out the trash in its place, eating healthy and balanced food and safe life behavior.
The habit of washing hands has been socialized and carried out for a long time, but it has not been carried out properly, using clean running water and soap, with the seven steps to wash hands properly. Children with special needs can be rather difficult to be told to do hand washing properly, especially those with moderate and severe disabilities. Washing hands with children with special needs is often done modestly, just soaking hands, then flicking or even leaving it wet. With children in general, this still happens a lot.

Maulani and Enterprise (2005) stated that the development of imperfect mental abilities results in several developmental delays, one of which is motion (motor). Delay in the coordination of the finger muscles, hands arms and mouth are some problems for children with special needs. Delay in motor development will certainly affect all activities involving the basic needs of children. In addition, impaired motor and cognitive functions also affect the ability to perform some self-care activities. Selfcare activities (self care) are all activities carried out by individuals to meet all needs to maintain life, health, and well-being in accordance with health and sickness.

Hand washing is an activity that is carried out every day. Washing hands is the basis for maintaining personal health and also preventive efforts from various diseases caused by dirty hands. The right time to wash hands is when after using the toilet, after coming into contact with dirty objects (rubbish), after playing activities, after indoor / outdoor activities, after defecation / urinating, before 
preparing food, before eating, and after touching animals, or other activities that require hand washing (for example after visiting / shaking hands with a sick person).

Every child can wash their hands. Washing hands uses the ability and coordination of the fingers. Thus, the prerequisite for being able to wash hands is motor skills, so that if there are children who experience motor barriers, motor training is necessary, although in reality, when washing hands, children also practice their motor skills.

Hand washing is very important in efforts to maintain children's health. Washing hands can reduce the incidence of diarrhea by $42-47 \%$, reduce accute respiratory syndrom (ARI) transmission by more than $30 \%$, and can reduce $50 \%$ the incidence of bird flu. Based on a WHO study, washing hands with soap can reduce diarrhea rates by $47 \%$.

Brushing teeth is also one of the most important things in maintaining oral health. Putra, Kandou, and Leman (2011) in his research at SLB YPAC Manado, found that in children with physical disabilities, mentally disabled and hearing impaired, those with good oral and dental hygiene were $29.03 \%$, the moderate category was $58.07 \%$ and the bad category is $12.9 \%$. Tooth and mouth hygiene that is not maintained in children with special needs, can cause various problems, including:

1) Cavities (carries)

2) Diseases of the tooth supporting tissue (periodontal)

3) Malocclusion occurs because of the delay in tooth eruption, no dental seed, the number of excess teeth, impaired muscle function in the mouth

4) Broksism (ngerot), especially in children with cerebral palsy, so that the teeth in the maxilla develop

5) Breathing through the mouth due to the narrowness of the respiratory tract

6) Trauma or impact

To prevent the aforementioned problems, brushing teeth becomes one of the most important efforts (Susanti, 2017). However, for children with special needs, brushing teeth is not easy. Based on the results of research Agustin (2014) it was found that the ability to brush teeth in children with ADHD in SLB Mutiara Hati, Sidoarjo, was in the poor category (47.99).

Regarding the diet of children with special needs, research shows that the type of snacks that children often consume is light food (97\%) and only $3 \%$ of children consume only food at home. Meanwhile, menus that are often made by parents are rice and eggs, porridge or rice and fried chicken. On the other hand, $60 \%$ of children only eat $1 / 2$ portion, with a frequency of eating 3 times a day. Thus, the need for improvement in children's diet. If in the early childhood education institution, teachers need knowledge about the types and menus of healthy food, so they can check the food of children brought from home or provide a balanced healthy diet if meals are provided by early childhood education institution.

Safe behavior is also important to understand and to be carried out by children, especially in school, because accidents are common. Accidents that can occur include falling, swallowing foreign objects, unhygienic consumption of food causing poisoning, burning, meeting dangerous strangers, and so on.

Clean, healthy and safe behavior is instilled early on through modeling, habituation and conditioning, so that it becomes a positive habit that persists and appears in the daily behavior of children. Early planting is very important because during this period a process of character building takes place, which will become the basis for the child's personality later, including clean, healthy and safe living behaviors.

Modelling is manifested by the example of positive behavior displayed by adults around children consistently. Habitualization is carried out all the time, every day, both in early childhood education institution and at home, so that continuity occurs, and it gets stronger. Conditioning is done by providing conditions that are conducive, so that the behavior can be owned, controlled, internalized and practiced in daily life.

Clean and healthy living behavior is important to instill early on, because this behavior can prevent children from various infectious diseases, even severe infectious diseases. Thus, it can improve the health status of children. The health status of children at an early age is very influential on the health status of children in the future. Safe behavior can prevent children from dangerous things, especially those in the early childhood education or home environment, for example unknown people who are dangerous, burning, slipping, exposed to sharp objects, and so on.

Clean, healthy and safe behavior is a daily behavior that is actually quite simple to practice, it's just that it often goes unnoticed, and is only carried out modestly. On the other hand, this is rather difficult to do for children who have special needs, because some of them require adequate physical motor, cognitive, language and social emotional skills, so planting clean, healthy and safe behavior in inclusive early childhood education has its own challenges.

Therefore, in some behaviors, it is simplified so that it can be done by children with special needs. In this model, children with special needs chosen are those who experience delays in speech, autism, and hyperactivity. The choice of these three special needs characteristics is partly due to the increasing number from year to year, and is often found in early childhood education institution.

\section{METHOD}

The research approach used is quantitative, with quasiexperimental designs. The activity was carried out at 3 playgroup institutions in Jombang Regency, which were a study group and 1 institution in Malang as a control group. In each institution 20 children were selected, and consisted of children without special needs and children with special needs with autism, hyperactivity and slow talk characteristics, but without concomitant disorders. Thus, the total target is 80 children in the playgroup. Before carrying out activities, teachers are given a technical orientation, so that they can carry out activities in 
accordance with the guidelines that have been designed. Teachers are given materials in the form of: 1) Clean, healthy and safe behavior Learning Model, 2) Clean, healthy and safe behavior Learning Guide, 3) Clean, healthy and safe behavior Card, 4) Picture Card Hand Washing Procedure, Tooth Brushing and Safe Behavior, 5) Healthy Food Teaching Materials for Early Childhood. The materials in the form of books are used by teachers as a guide, while those in the form of cards are used when playing with children. The activity was carried out during 12 meetings, with 8 assistance.

\section{DEVELOPMENT AND DISCUSSION RESULTS}

Clean, healthy and safe living behaviors in early childhood education are implemented using two patterns, namely:

1) Integrated in other themes

2) There are separate themes related to clean, healthy and safe behavior, and continued with integration in other themes

Clean, healthy and safe behavior which is integrated with other themes is carried out every day, adjusting to the activities carried out on that day. For example, washing hands after activities play, before and after eating, and after handling trash. Tooth brushing activities are adjusted to the activities of each school, and if there are eating activities, brushing is done after eating. The activity of disposing of garbage is done every time there is an activity that generates garbage. Eating together activities, adjusted to the schedule of each early childhood education institution and prioritized for activities that eat staple foods. Meanwhile, other activities continued as stated in the learning plan.

Clean, healthy and safe behavior is carried out with its own themes carried out at the beginning of the school year, when the child has just entered the Early childhood education institution (for about 9 weeks), for initial recognition and habituation, then continues to be integrated with other learning themes and activities. Themes and sub-themes related to clean, healthy and safe behavior include:

1) I am an Indonesian child/ my body is healthy

2) My favorite/ nutritious food

3) My School/ School Environment is Safe and Comfortable

Learning subject matter that can be used include:

1) My body is God's creation

2) How to wash hands

3) How to brush your teeth

4) My body

5) Communication

6) My hobbies

7) Arts

Thus, the initial introduction is an enrichment of experience, which will facilitate the implementation of the next habituation.
Child development outcomes for the five behaviors that are instilled, familiarized and conditioned are as follows:

\subsection{Washing Hands}

All children without special needs can wash their hands in seven steps, but $80 \%$ have not been able to do it in sequence. For children with special needs they can only do three steps, namely wet hands, soaping and drying. The ability to wash hands is greatly influenced by gross and fine motor development, cognitive, and language. For children with special needs with three categories that are targeted activities, in general, have not been well developed, so the achievements are different from children in general. Nevertheless, basically all children can do it.

\subsection{Brushing Teeth}

Brushing your teeth regularly can prevent dental health problems, including dental carries caused by the gathering of disease germs and then damaging teeth, or decaying food debris and then becoming a breeding ground for germs. Therefore, tooth brushing behavior needs to be familiarized with early on. Brushing teeth can be done by all children, although the achievements are different, and very much depends on the development of fine motor skills and the child's ability to focus. The activity of brushing teeth at first was not liked by the children, because of the strange taste of the paste, the uncomfortable brush bristles, the condition of the teeth that had caries, or had not been accustomed to by the parents. Development results show that $70 \%$ of children without special needs can brush their teeth in five steps, namely pouring toothpaste on a toothbrush, gargling, brushing the front, brushing the sides, and gargling again to clean the mouth. For children with special needs, all of them can do three steps, namely pouring toothpaste on a toothbrush, gargling, brushing the front teeth, and gargling again, even when gargling, still swallowing water. For gargling, boiled water is used for children with special needs.

\subsection{Disposing of Trash in Its Place}

Activities to dispose of garbage are integrated with eating together, in the form of disposing leftovers or food wrappers in their place. All children without special needs can dispose of trash in their place, and all children with special needs can dispose of trash in its place with the guidance of teachers.

\subsection{Consumption of Nutritious, Healthy and Balanced Food}

Consumption of nutritious, healthy and balanced food in children at first is not optimal. There are still many 
children who bring lunch from home in the form of fast food, packaging, or other types of nutritional value that is inadequate. When eating together, there are some children who initially refused the food provided. However, when eating together is done every day, and teachers provide assistance, in general, $95 \%$ of children with no special needs can consume a variety of foods, especially traditional foods and those derived from local food. All children with special needs can consume food according to their specialty. At the end of the eating activity, the children are also trained in their independence to throw food scraps in the trash, do the sorting of tableware, washing tableware. Joint food activities from beginning to end then turn out to be fun activities for children. Many skills are eventually learned by children, including gratitude to God Almighty, independence, cooperation, discipline, mathematics, fine and gross motor skills, queuing culture, introduction of various types and flavors of food, simple technology in the form of cutlery.

\subsection{Safe Behavior}

Safe behavior is instilled and accustomed to children with the aim of reducing accidents that exist in school, increasing the child's preparedness and alertness to the dangers that may occur in school, choosing people who are free of hazardous materials, and being aware of strangers. All children gradually understand safe behavior with the guidance of teachers. Safe behavior exhibited by children is quite varied, and needs to be improved, including:

1) Using sharp objects (scissors and forks) carefully

2) Carrying dirty eating and drinking utensils carefully

3) Washing tableware and drinking carefully

4) Washing dishes and drinking utensils carefully

5) Toileting carefully

Learning tools consist of learning planning, assessment of the development of clean, healthy and safe living behaviors. Learning planning consists of a semester

Table 1 Significance of children clean, healthy and safe behavior

\begin{tabular}{|l|l|l|}
\hline \multicolumn{1}{|c|}{ Behavior } & \multicolumn{1}{|c|}{ p Conclusion } \\
\hline Washing hands & 0.002 & Significant \\
\hline Brushing teeth & 0.000 & Significant \\
\hline $\begin{array}{l}\text { Consuming various and healthy } \\
\text { food }\end{array}$ & 0.002 & Significant \\
\hline Throwing garbage & 0.0001 & Significant \\
\hline Safe life behavior & 0.002 & Significant \\
\hline
\end{tabular}

\section{CONCLUSIONS AND SUGGESTIONS}

The results of the development show that clean, healthy and safe behavior learning can be done for all children, although in the end the development achievements are

program, a weekly learning implementation plan, and a daily learning implementation plan, which is equipped with an observation instrument for the development of clean, healthy and safe living behaviors, both for children in general and for children with special needs.

Learning planning can be developed by early childhood education institution in accordance with existing conditions. Assessment of child development consists of instruments for assessing the development of clean, healthy and safe living behaviors. The assessment can also be developed by early childhood education institution in accordance with the conditions of each unit.

The whole learning tool is presented for example in detail, so it is expected to be an inspiration for teachers to develop it. Besides it is also expected that the whole is in accordance with the unit conditions and characteristics of the children being served. Learning tools are used by teachers in play groups, who have children in general and children with special needs. Learning tools can be simplified by each early childhood education institutions, as long as all components are complete. Likewise with the format, it can be developed according to the principle of simplicity and simplicity.

The semester, weekly and daily program, in learning clean, healthy and charitable behavior, is divided into two types, namely:

1) Integrated with other themes in early childhood education institution units

2) Based on specific themes related to clean, healthy and safe living behaviors

At the beginning of the semester teachers can determine in advance, the pattern to be selected, namely pattern 1 or pattern 2, according to the conditions in each playgroup. From the whole process, there are changes in children's behavior, which are generally presented in the following table. different. All children can be familiarized and conditioned to have a clean, healthy and safe lifestyle. It is recommended that research and development related to other clean, healthy and safe behavior be conducted on children, their relationship with life skills, and improve the 
skills of teachers to accompany children to habituate clean, healthy and safe living behaviors. Habitualization needs to be done in the family, so that it can strengthen the attitudes, knowledge and skills of children about clean, healthy and safe life and need further research into the relationship between planting clean, healthy and safe living behaviors with basic life skills that children must master from an early age.

\section{REFERENCES}

Agustin, D. (2014). Penggunaan metode demonstrasi terhadap kemampuan menyikat gigi pada anak ADHD (Attention Deficit Hyperactivity Disorder). Jurnal

Pendidikan Khusus, 6(6), 1-6.

Maulani, C., \& Enterprise, J. (2005). Kiat merawat gigi anak panduan orang tua dalam merawat dan menjaga kesehatan gigi bagi anak-anaknya. Jakarta: PT. Elex Media Komunikasi.

Putra, N., Kandou, J., Leman, M. A. (2011). Gambaran Kebersihan Gigi dan Mulut pada Anak Cacat di YPAC Manado (Bachelor thesis). Manado. Universitas Sam Ratulangi. Retrieved from https://digilib.unsrat.ac.id/

Susanti, L. (2017). Permasalahan gigi dan mulut.

Jakarta: Flexicare. 